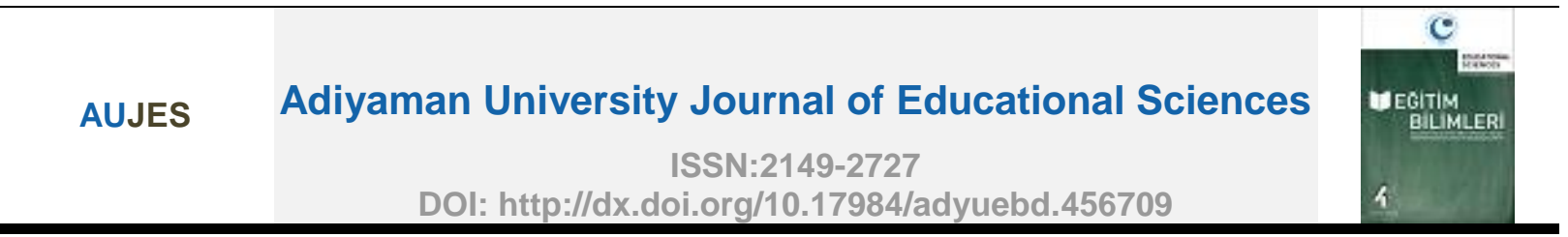

\title{
The Relationship Between School Administrators' Conflict Management Styles and Organizational Health ${ }^{*}$
}

\author{
Kazım ÇELIK ${ }^{1}$, Ali TOSUN ${ }^{2^{\star \star}}$ \\ ${ }^{1}$ Pamukkale University, Faculty of Education, Department of Educational Sciences, Turkey \\ ${ }^{2}$ Pamukkale University, Institute of Educational Sciences, Turkey
}

ARTICLE INFO

\section{Article History:}

Received

01.09 .2018

Received in revised

form 12.03.2019

Accepted

10.05.2019

Available online

30.06.2019

Article Type:

Research Article

\begin{abstract}
It is natural to appear conflict occasions in the place where individual interests and needs differ from schools(educational organizations). That conflict processes manage through organizational profits is quite important for continuing organizational life in a healthy way. In this way, the research has been implemented among 349 primary, secondary and high school teachers in Uşak in view of the relationship between conflict management strategies which are used by school managers in conflicts apeearing in schools and organizational health in schools. According to research results, teachers generally think that the schools are highly healthy organizations. In a relationship with conflict management strategies, teachers think that school managers have highly used obliging and compromising strategies; moderately avoiding and integrating strategies; seldom dominating styles. Besides according to the results whether there is a relationship between conflict management strategies and organizational health or not, in order to manage conflicts, the relationship between integrating and compromising styles school managers have used and organizational health are highly positive, relationship between obliging styles and organizational health are medium level, the relationship between dominating styles and organizational health negatively low. It is seen there is no significant relationship between avoiding styles and organizational health. According to research results, among conflict management styles, integrating, obliging and compromising dimensions have significantly predicted in organizarional health.
\end{abstract}

(c) 2019 AUJES. All rights reserved Keywords: Management, Conflict, Organizational health.

\section{Extended Abstract}

\section{Purpose}

Individuals struggle to achieve goals that they can not achieve on their own, either by joining organizations or by creating new organizations. Organization administers who struggle to be an effective organization face many difficulties. It can be said that one of the

\footnotetext{
"In this study the 13th International Congress on Educational Administration(13.ICEA) in the presented as oral presentations "The Relationship Between School Administrators' Conflict Management Styles and Organizational Health" extended from the study and edited version.

${ }^{* *}$ Corresponding author' address: Ali TOSUN, Pamukkale University, Institute of Educational Sciences, Denizli, Turkey e-mail: ali35tosun@gmail.com
} 
most important difficulties that administrators face in trying to provide organizational effectiveness is organizational conflict (Aksu, 2003). It is natural that uncompromising situations arise in organizations formed by individuals with different beliefs and values (Yıldızoğlu, 2013). Conflicts that arise in schools that are educational organizations should be managed by school administrators in line with the goals of the school. Organizational health is the same as a healthy person, no organ to conflict with each other, contradictory to work regularly without falling (Başaran, 1994). Organizations, like human beings in the functioning of organs, are considered as healthy if they fulfill their functions, and their health depends on the compatibility of all the components of the organization. According to Uras (2000), organizational health is much more important for educational organizations than any other organization, because educational organization's data is human. For this reason, it can be argued that managing the conflict processes without harming the organizational effectiveness in order to protect the health of the schools is very important for being a healthy organization. This research aims to measure the relationship between conflict management styles used by school administrators in school conflicts and organizational health of schools.

\section{Method}

Research that aims at measuring the relationship between organizational health and conflict management styles used by managers in educational organizations is the relational screening model.. The relational screening model is a research model aiming to describe a situation that existed in the past or continues to exist today. The subject of the research, individual or object, is tried to be defined as it exists in its own conditions. The relational screening model is a model that aims to describe the existence of change or the degrees of it between two or more variables. It has two screening models as correlation and comparative model. With the comparing way used in this research, there should be at least two variables in determining the relationship and the groups are created according to one of them (independent variable) and it is examined whether there is a differentiation between them (Karasar, 2016). In this research the conflict management styles of school managers were mentioned as independent, organizational health dependent variable.

\section{Results}

According to the results obtained in the research, teachers think that school administrators generally use compromising styles and compromises in high level conflict situations. Moderate integration and avoidance styles from other dimensions of conflict management styles; and that they use the ruling style at a low level. There was no significant 
difference in terms of integration, compromise and avoidance from the conflict management styles used by school administrators according to gender and school level variables; it was also found that there was a significant difference between the groups in terms of dominance and compromise according to the same variables. When we look the results of the survey on organizational health, teachers generally think that schools are healthy organizations at a high level. When the perceptions of the teachers' organizational health dimensions are examined, it is seen that perceptions towards organizational leadership dimension is very high and perceptions about other dimensions of organization health such as organizational integrity, organizational identity, organizational product and environmental interaction dimensions are high. When the perceptions of organizational health were examined by gender and school level variables, it was seen that there was no significant difference between groups in all of the organizational health and in all sub dimensions. It has been seen that school administrators have a high degree of positive relationship between organizational health and the use of integration and compromise styles to manage conflicts. In the results of regression analysis obtained within the scope of the research, integration, compromising, and compromising styles in conflict management styles significantly predict organization health.

\section{Discussion}

Generally, teachers think that schools are high-level healthy organizations. Taneri (2011), Ayduğ and Ağaoğlu (2014) also found that their teachers' schools assessed organizational health at a high level. When the perceptions of organizational health were examined by gender and school level variables, it was seen that there was no significant difference between groups in all of the organizational health and in all sub dimensions. In parallel with the results of the research, it is seen that there is no meaningful difference in the perceptions of the teachers' gender variable in the perceptions of the whole organization health in the studies done by Akbaba (1997), Özdemir (2006), Edwards (2008), Ebcim (2012) and Ayduğ (2014). It has been seen that school administrators have a high degree of positive relationship between organizational health and the use of integration and compromise styles to manage conflicts. According to Rahim $(1985,2001)$, the integration style, which is an acceptable solution for both sides of the conflict, is also called problem solving. Reconciliation style is also defined as negotiating on a common point without separating the ends of the parties. In this case, it can be said that the school administrators have been studying the differences in reaching the solution in the conflict situations, and the efforts of both sides to give up something and reach the common point have increased the organizational health levels of the schools to a high level. Because according to Başaran (1998), conflicts that arise in healthy schools need to be resolved in the direction of 
organizational goals. According to the results of the regression analysis obtained, the integration style, compromise and compromise styles in the conflict management styles significantly predict the organizational health. It has been determined that there is a low level of negative relationship between governance style and organizational health, which is one of the conflict management styles and which is defined as the one side of the conflict parties ignoring one's thoughts about their own needs. Ransom's study of 1990 in order to determine the relationship between school health and the items of participatory management has also found that schools managed by the participation of all employees, not school administrators' orders, are healthier organizations (Akbaba, 1997). In this case, it can be said that the school administrators 'attempts to accept the school administrators' unconsciousness to their counterparts in the conflict situations negatively affects the organizational health. Moreover, it seems that there is no meaningful relationship between avoidance style of conflict management style and organizational health.

\section{Conclusion}

According to research findings, school administrators should know the conflict management styles in order to direct conflict processes in organizations towards organization goals. School administrators who want their organizations to survive in good health must know exactly which strategy should be used in conflict situations with teachers. 


\title{
ADYÜEBD Adıyaman Üniversitesi Eğitim Bilimleri Dergisi \\ Okul Yöneticilerinin Çatışma Yönetim Stilleri İle Örgütsel Sağlık Arasındaki İlişki*
}

\author{
Kazım ÇELIK ${ }^{1}$, Ali TOSUN ${ }^{2 *}$ \\ ${ }^{1}$ Pamukkale Üniversitesi, Eğitim Fakültesi, Eğitim Bilimleri Bölümü, Türkiye \\ ${ }^{2}$ Pamukkale Üniversitesi, Eğitim Bilimleri Enstitüsü, Türkiye
}

MAKALE BILLGI

Makale Tarihcesi: Alındı 01.09.2018

Düzeltilmiş hali

alındı 12.03.2019

Kabul edildi

10.05.2019

Çevrimiçi yayınlandı

30.06.2019

Makale Türü:

Araştırma Makalesi

\section{ÖZET}

Eğitim örgütleri olan okullarda bireysel ilgi ve ihtiyaçların farklılaştığı noktalarda çatışma durumlarının oluşması doğaldır. Çatışma süreçlerinin örgütsel çıkarlar doğrultusunda yönetilmesi örgütün yaşamını sağlıklı bir şekilde devam ettirebilmesi için oldukça önemlidir. Bu düşünceden hareketle araştırma, okul yöneticilerinin okullarda meydana gelen çatışmalarda kullandıkları çatışma yönetim stilleri ile okulların örgütsel sağlığı arasındaki ilişkinin belirlenmesi amacıyla, Uşak ilinde görev yapan 349 ilkokul, ortaokul ve lise öğretmeni ile gerçekleştirilmiştir. Araştırma sonuçlarına göre, öğretmenler genel olarak, okulların yüksek düzeyde sağlıklı örgütler olduğunu düşünmektedirler. Çatışma yönetim stilleri ile ilgili olarak öğretmenler genel olarak yüksek düzeyde okul yöneticilerinin çatışma durumlarında ödün verme ve uzlaşma stillerini kullandıklarını; tümleştirme ve kaçınma stillerini orta düzeyde; hükmetme stilini ise düşük düzeyde kullandıklarını düşünmektedirler. Ayrıca araştırmada okul yöneticilerinin okullarda meydana gelen çatışmalarda kullandıkları çatışma yönetim stilleri ile okulların örgütsel sağlığı arasında bir ilişki olup olmadığına yönelik ulaşılan sonuçlara göre, okul yöneticilerinin çatışmaları yönetmek için tümleştirme ve uzlaşma stillerini kullanması ile örgüt sağlığı arasında pozitif yönde yüksek derecede; ödün verme stilini kullanması ile örgüt sağlığı arasında pozitif yönde orta düzeyde; hükmetme stilini kullanması ile örgüt sağlığı arasında negatif yönde düşük derecede bir ilişki olduğu tespit edilirken çatışma yönetim stillerinden kaçınma stili ile ise örgüt sağlığı arasında anlamlı bir ilişki olmadığı görülmüştür. Yine araştırma sonuçlarına göre çatışma yönetim stillerinde tümleştirme, ödün verme ve uzlaşma stillerinin örgüt sağlığını anlamlı bir şekilde yordadığı görülmüştür.

(c) 2019 AUJES. Tüm hakları saklıdır Anahtar Kelimeler: Yönetim, Çatışma, Örgüt sağlığı.

\section{Giriş}

Örgütler yaşamlarını sürdürebilmek için sürekli olarak çevreleriyle etkileşim halindedir. Gelişen ve yenilenen çevre ile uyum düzeyi, örgütün hedeflerine ulaşabilme durumunu etkilemektedir. Örgütsel hedeflere erişmede doğru yolda ilerleyen örgütler gelişimlerini sağlıklı bir şekilde devam ettirebilirler. Örgütler gelişen çevreye uyum için duyduğu gereksinimleri karşılayabilmeli ve örgüt içerisinde ortaya

\footnotetext{
*Bu çalışma 13. Uluslararası Eğitim Yönetimi Kongresi (13. EYK)'nde Sözlü bildiri olarak sunulan "Okul Yöneticilerinin Çatışma Yönetim Stilleri İle Örgütsel Sağlık Arasındaki İlişki” adlıçalışmanın genişletilmiş ve düzenlenmiş halidir.

**Sorumlu yazarın adresi: Ali TOSUN, Pamukkale Üniversitesi, Eğitim Bilimleri Enstitüsü, Denizli, Türkiye

e-posta: ali35tosun@gmail.com
} 
çıkan çatışmaları örgütsel hedefler doğrultusunda yönetebilmelidir. Örgüt içerisinde meydana gelen çatışma durumları genel olarak olumsuz bir anlam ifade etmesine karşın, doğru yönetildiği takdirde örgütsel hedeflere ulaşmada etkin bir araç olarak kullanılabilmektedir. Bu nedenle geleceğin inşasında önemli bir misyonu olan eğitim örgütlerinde de çevreye uyum sürecinde ortaya çıkan çatışmaların örgütsel hedefler doğrultusunda yönetilebilmesi okul sağlığı açısından önem taşımaktadır.

Literatürde okul yöneticilerinin örgütsel süreçlerdeki davranışlarının örgüt iklimi ile yakından ilişkili olduğunu gösteren birçok çalışma bulunmaktadır (Tuna, 1996; Bayram, 2012; Çatakdere,2014; Ayık ve Diş, 2015; Avcı, 2016; Diş ve Ayık, 2016). Cemaloğlu' na (2007) göre de olumlu bir okul iklimini ifade eden örgüt sağlığının oluşumunda okul yöneticilerinin liderlik özellikleri önemli bir değişkendir. Çünkü okul yöneticilerinin taraf olduğu ve olmadığı çatışma durumlarını aynı objektiflikle yürütebilmesi için liderlik konusunda geniş bilgi sahibi olması gerekmektedir(Koçak ve Baskan, 2013). Bu anlamda okul yöneticilerinin kullanmış oldukları çatışma yönetim stilleri liderlik özelliklerinin de bir sonucu olarak ortaya çıktığı düşünülebilir. Bu araştırma sonucunda da ortaya çıkacak olan hangi çatışma yönetim stillerinin örgüt sağlığı açısından daha yordayıcı olduğu sonucu etkili bir liderin özelliklerini açıklamada yeni bir özellik olabileceği düşünülmektedir.

Örgütsel sağlık kavramının canlılardaki sağlık durumları ile metaforlaştırılması, örgütünde tıpkı insanlardaki organların işlevlerini yerine getirmesi durumunda sağlıklı olarak nitelendirilmesi gibi örgütlerinde sağlığı, örgütün tüm bileşenlerinin birbiri ile uyumlu bir şekilde çalışmasına bağlıdır. Örgütsel sağlık, aynı sağlıklı bir insanda olduğu gibi, hiçbir organın birbiri ile çatışmaya, çelişkiye düşmeden düzenli olarak çalışmasıdır (Başaran, 1994). Miles' a (1965) göre sağlıklı bir örgüt, kısa süreli etkililiğin ötesine geçebilmelidir. Bu anlamda sağlıklı bir örgüt sadece kendi ortamında ayakta kalmakla değil, aynı zamanda uzun mesafeli bir şekilde kendini geliştirme, hayatta kalma ve başa çıkma yeteneklerini sürekli olarak geliştirir ve genişletir. Bu anlamda çalışma kapsamında öğretmenlerin örgütsel sağlık algılarının belirlenmesi eğitim örgütü olan okulların hayatta kalma süreçlerinde öğretmenler tarafından nasıl algılandıklarının anlaşılmasında faydalı olabilir.

Uras' a (2000) göre örgütsel sağlık etkenlerini iyileştirerek çalışanların iş edimini etkilemek tüm örgütler için önemlidir. Ancak, eğitim örgütlerini diğer örgütlerden farklı kılan bir özelliği girdisi, süreçte yer alanlar ve çıktısı insan olması nedeniyle, örgüt sağlığı eğitim örgütleri için diğer tüm örgütlerden çok daha fazla önemlidir. Başaran (1994) okulun, eğitim hizmetlerini üreten temel sistem olarak etkili çalışmak zorunda olduğunu vurgulayarak, okulun sağlığını korumak için işgörenler arasında çatışmayı en aza indirerek eğitim işgörenlerini birlik içinde, eğitim amaçlarını gerçekleştirmek için yöneltmek gerektiğini savunmaktadır. Korkmaz' ın (2011) yapmış olduğu çalışmada da örgüt sağlığı ile çalışanların örgütsel amaçları benimsemeleri ile yakından ilişkili olan örgütsel bağlılık arasında güçlü bir ilişki olduğu görülmüştür. Bu nedenle ülkelerin geleceğinin inşa edildiği okullarda örgütsel yaşamın doğal bir sonucu olarak ortaya çıkabilen çatışma süreçlerinin örgütsel etkililiğe zarar vermeden yönetilebilmesi sağlıklı okul olabilmek için oldukça önemli olduğu söylenebilir. Bu noktada okulların sağlıklı ya da sağlıksız olarak 
nitelendirilebilmesi için hangi kriterlerin göz önünde bulundurulacağının bilinmesi gerekmektedir.

Hoy ve Feldman (1987) örgüt sağlığı ölçeği geliştirmek için yapmış oldukları çalışmada sağlıklı ve sağlıksız okullar için belirli kriterler koymuşlardır. Buna göre, "Sağlıklı okul” çevreden gelen baskılardan korunur. Sağlıklı okulların yönetiminde görev alanlar, okulda uygulanmaya çalışılan politikalara müdahale etmesi muhtemel olan çıkar gruplarının tüm çabalarına karşı sonuna kadar direnirler. Sağlıklı bir okulun müdürü hem göreve yönelik hem de ilişki odaklı lider davranışlarını bütünleştiren dinamik bir liderdir. Bu yöneticiler öğretmenleri destekleyerek yüksek performans için yüksek standartlar sunarlar. Ayrıca, okul müdürü okulun etkili çalışması için gerekli olanları elde edebilecek yetenekleriyle üstlerine karşı etki gücüne sahiptir. Sağlıklı okullardaki öğretmenler öğretmeye ve öğrenmeye uygundurlar. Bu öğretmenler öğrenciler için yüksek ama başarılabilir hedefler belirler, yüksek performans standartlarını korur, ciddi ve düzenli bir öğrenme ortamını destekler. Sağlıklı okullardaki öğrenciler ise okulda verilen ödevler için çok çalışırlar, yüksek motivasyona sahiptirler ve akademik olarak başarılı diğer öğrencilere saygı duyarlar. Sağlıklı okullarda ders için gerekli materyaller her zaman mevcuttur ya da elde edilebilir. Ayrıca sağlıklı okullarda görev yapan öğretmenler birbirlerine güvenirler, yaptıkları iş konusunda heveslidirler, okullarına karşı olumlu düşüncelere sahiptirler ve okulları ile gurur duyarlar. "Sağlıksız okul” ise yıkıcı dış güçlere karşı savunmasızdır. Öğretmenler ve idareciler sürekli olarak anne-babaların mantıksız taleplerine maruz kalırlar. Sağlıksız okulların kesin olarak belirlenmiş prensipleri yoktur. Bu okullardaki müdürlerin etkili liderler değildirler. Sağlıksız okullarda görev yapan müdürler çok az sayıda üst yöneticiyi tanılar ve tanıdıkları üzerinde de herhangi bir etki güçleri yoktur. Öğretmenler, meslektaşları ve meslekleri hakkında olumlu düşünmezler. Öğretmenler birbirlerinden ayrı hareket ederler, şüpheci ve savunmacıdırlar. Sağlıksız okullarda ders için gerekli materyaller temin edilmez ya da olanlar intiyaca cevap vermez. Sonuç olarak, sağlıksız okullarda akademik mükemmeliyet kaygısı yoktur. Ne öğretmenler nede öğrenciler akademik süreçleri ciddiye almazlar. Akademik olarak başarılı öğrenciler, akranları tarafından alaya alınır ve öğretmenler tarafından bu başarılı öğrenciler tehdit unsuru olarak algılanır.

Örgütlerin sağlıklı ya da sağlıksız olduğunu belirleyebilmek için dünyada birçok çalışma yürütülmüştür. 1965 yılından itibaren "örgüt sağlığı" kavramı özellikle Matthew B. Miles ve Wayne K. Hoy' un dikkatini çekmiş, araştırmalar doğrultusunda bu kavramı tanımlamışlar, önemini vurgulamışlar ve daha sonra da örgüt başarısı için oldukça önemli olduğunu savundukları örgüt sağlığı kavramını ölçebilmek için boyutlar geliştirmişlerdir. (Polatçı, Ardıç, Adem, 2008). Türkiye'de de bu amaçla örgütsel sağlığı belirleyebilmek için bir çok çalışma yürütüldüğü görülmektedir (Özdemir, 2006; Cemaloğu, 2007; Korkmaz, 2011; Ordu, 2011; Recepoğlu ve Özdemir, 2013; Yüceler, Doğanalp, ve Kaya, 2013). Mevcut çalışmada okulların örgütsel sağlık düzeylerini belirlemek amacıyla Akbaba (1997) tarafından yapılan örgüt sağlığı envanteri kullanılması nedeniyle Akbaba (1997) tarafından örgütlerin sağlıklı ya da sağlıksız özelliklerini ölçebilmek için geliştirilen 5 boyutun açıklanması yerinde olacaktır. İlk boyut olan (1) Örgütsel Liderlik, örgüt amaçlarının belirlenmesi 
ve belirlenen amaçların nasıl gerçekleşeceğinin planlanmasıdır. Ayrıca eldeki kaynakların belirlenen amaçları gerçekleştirmek için nasıl kullanılacağının belirlenmesi ile örgütsel standartların hazırlanması ve geliştirilmesidir. Bir diğer boyut olan (2) Örgütsel Bütünlük, çevre baskılarına karşı örgütün korunması, örgüt içinde bulunanların dinamik bir ilişki sağlayarak bir arada olmaları durumudur. Bir diğer boyut (3) Çevresel Etkileşim ise örgütün iç ve dış çevresi ile etkili bir iletişim kurmasıdır. Örgütlerin teknolojiye uyum sağlaması; toplumun ihtiyaçlarına cevap verebilmesi ve çevresi ile bağlarının güçlü olması örgütsel sorunların çözümünü kolaylaştırabilir. Bir başka boyut (4) Örgütsel Kimlik boyutudur. Bu boyut bir eğitim örgütü olan okulu diğer örgütlerden farklılaştıran, okulun sahip olduğu gücü gösteren, okulun moral durumunu temsil eden ve okula ilişkin çıkarımlarda bulunmayı sağlayan özellikleri temsil etmektedir. Son boyut olan (5) Örgütsel Ürün, örgütün dönüt almasıdır. Dönüt alan örgütler, kaynak kullanımını değerlendirerek okulu etkili kılar ve sağlıklı ürünler verir.

Sonuç olarak sağlıklı örgüt hedeflerine etkili bir biçimde ulaşabilmek, yaşamını sürdürmek, gelişebilmek ve yenilenebilmek için duyduğu intiyaçları karşılayabilmeli, çalışanlar arasında ortaya çıkan çatışmaları örgütsel amaçlar doğrultusunda yönetebilmeli ve çalışanların örgütsel zorlanmaya düşürülmeden örgüte uyumunu sağlayabilmelidir (Başaran, 1998). Bu anlamda örgüt içerisinde meydana gelen çatışma durumlarında yöneticilerin davranış biçimleri örgüt içerisindeki atmosferi doğrudan etkileyeceği söylenebilir. O halde örgüt içerisinde meydana gelen çatışma durumlarında okul yöneticilerinin çatışma durumlarında kullandıkları çatışma yönetim stillerinin okulların sağlık düzeyleri ile olan ilişkilerinin belirlenmesi önem kazanmaktadır. Bu noktadan hareketle çalışmada yukarıda açıklanan örgüt sağlığı ile eğitim örgütü olan okullardaki yöneticilerin kullandıkları çatışma yönetim stilleri arasındaki ilişki belirlenmeye çalışılmıştır. Bu anlamda araştırmanın diğer değişkeni olan çatışma yönetiminin açıklanması yerinde olacaktır.

Bireyler örgütlere dahil olarak ya da yeni örgütler oluşturarak tek başlarına gerçekleştiremedikleri hedeflere ulaşabilmek için çaba harcarlar. Etkili bir örgüt olmak için çaba harcayan örgüt yöneticileri ise birçok zorlukla karşılaşabilmektedirler. Örgütsel etkililiği sağlama çabasında olan yöneticilerin karşılaştıkları en önemli zorluklardan birinin örgütsel çatışma olduğu söylenebilir (Aksu, 2003). Örgütsel yaşamın kaçınılmaz bir gerçeği olan çatışma, bireyler ve grupların birlikte çalışma sorunlarından kaynaklanan ve normal faaliyetlerin durmasına veya karışmasına neden olan olaylar olarak tanımlanabilir (Eren, 2016).

Farklı fikir ve değerlere sahip bireyler tarafından oluşan örgütlerde uzlaşamama durumlarının ortaya çıkması doğaldır. Temel girdisi insan olan eğitim örgütlerinde de insanlar arası etkileşim yoğun olduğu için çatışma durumları ortaya çıkmaktadır (Yıldızoğlu, 2013; Karip, 1999). Eğitim örgütü olan okullarda ortaya çıkan çatışma durumları okul yöneticileri tarafından okulun hedefleri doğrultusunda yönetilmelidir. Tanrıverdi (2008) tarafından eğitim örgütlerinde yapılan araştırmada, okul yöneticilerinin kullandıkları çatışma yönetim stilinin okulun örgüt iklimi ile ilişkili olduğu; Erol (2009) tarafından yapılan bir araştırmada da okul yöneticilerinin kullandıkları çatışma yönetim stili ile öğretmenlerin stres düzeyleri arasında ilişki 
olduğu belirlenmiştir. Bu anlamda okul yöneticileri çatışma durumlarında çözüm metotlarını sorgulayarak okulun etkililiğini sürdürebilmesi için en uygun stratejiyi kullanması gerekmektedir (Önk, 2015).

Alanyazın incelendiğinde bireyler arasında çıkan çatışmaları yönetmek için çeşitli davranış stilleri ileri sürülmüş ve bu stilleri açıklamak için değişik modeller geliştirilmiştir. Çatışma yönetimi stilleri ile ilgili teknikleri ilk defa 1964 yılında sistematik ve analitik olarak inceleyen düşünürler Blake, Shepard ve Mouton'dur (Eren, 2016). Thomas 1976 yılında Blake, Shepard ve Mouton tarafından geliştirilen modeli yeniden yorumlayarak genişletmiştir. Blake, Shepard ve Mouton ile Thomas'ın çalışmalarından esinlenen Rahim ve Bonoma 1979 yılında çatışma durumlarında kişinin kendi ilgi ve intiyaçlarını doyurma derecesi ile karşısındakinin ilgi ve intiyaçlarını doyurma derecesine göre beş çatışma yönetim stilini (tümleştirme, ödün verme, hükmetme kaçınma, uzlaşma) içeren başka bir model geliştirmiştir (Gümüşeli, 1994; Himmetoğlu, 2014; Rahim, 2001). Alanyazında birçok araştırmada (Bağdatlı, 2015; Erol, 2009; Gümüşeli, 1994; Horata, 2013; Rahim, 2001; Karcıŏlu, Gövez ve Kahya, 2011; Koç, 2016; Korkmaz, 2013; Odabaşığlu, 2013; Önk,2015; Tanrıverdi, 2008; Toytok ve Açıkgöz, 2013; Yiğit, 2015) bu beşli sınıflandırma modeli kullanılması nedeniyle bu araştırmada da Rahim ve Bonoma (1979) tarafından geliştirilen beşli model esas alınmıştır. $\mathrm{Bu}$ beş farklı çatışma yönetim stilinin açıklamalarına baktığımızda: ilk boyut olan (1)Tümleştirme Stili, çatışma tarafları arasında bilgi alışverişini ve her iki taraf için de kabul edilebilir bir çözüme ulaşmak için farklılıkları incelemeyi içerir. Bu stil yaratıcı çözümlere yol açabilecek problem çözmeyi içerir (Rahim ve Bonoma, 1979). Bu nedenle bu stil problem çözme olarak adlandırılır. Taraflar arasında işbirliğini (yani, açıklık, bilgi alışverişi ve her iki taraf için kabul edilebilir bir çözüme ulaşmak için farklılıkların incelenmesi) içerir (Rahim, 2001). Follet'a (1926) göre tümleştirmeyi elde etmek için ilk kural, kartlarınızı masaya koymak, gerçek meseleyle yüzleşmek, çatışmayı açığa çıkarmak, her şeyi açık duruma getirmektir. Bu stil konular karmaşık olduğunda farklı bakış açılarının birleşimi ile çatışmaları çözmesi nedeniyle uzun vadeli planlamalarda kullanımı uygun olabilir (Rahim, 1985). Bir diğer boyut olan (2)Ödün verme Stili, çatışmalarda diğer tarafın endişesini gidermek, ilgi ve ihtiyaçlarını ön plana çıkarmak için kişinin kendi ilgi ve ihtiyaçlarından vazgeçmesi durumunda kullanılır (Rahim, 1985). Çatışma taraflarından birinin diğer taraftan gelecekte bir beklenti içinde olması durumunda strateji olarak kendi intiyaçlarını inmal ederek bu stili kullanabilir (Rahim ve Bonoma, 1979). Meselenin diğer taraf için çok daha önemli olduğu durumlarda faydalı bir yaklaşımdır (Rahim, 1985). Bu stilin kullanılmasında bir özveri unsuru vardır (Rahim, 2001).Bir başka boyut olan (3)Hükmetme Stili, çatışma taraflarından birinin intiyaçlarını karşılamak için diğer tarafın ilgi ve intiyaçlarını göz ardı ederek kendi düşüncelerini mutlak doğru olarak kabul ettirmeye çalışması durumudur (Rahim, 1985). Bu stilde zorlayıcı davranışlar söz konusudur. Bazen egemen bir kişi her ne pahasına olursa olsun kazanmak ister. Bu durumda kendi konum gücünü kullanarak düşüncelerini karşı tarafa koşulsuz kabul ettirmeye çalışır (Rahim, 2001). Çatışmaya konu olan meseleler önemsiz olduğunda ya da hızlı karar verilmesi gerektiğinde bu tarzı kullanmak uygun olabilir (Rahim ve Bonoma, 1979). Ayrıca bu stil, daha üst 
düzey yönetim tarafından formüle edilen stratejileri ve politikaları uygulamak için de uygundur (Rahim, 1985). Bir diğer boyut ise (4)Kaçınma Stili boyutudur. Kaçınmak, geri çekilme durumu ile ilişkilendirilmiştir. Kaçınma stili, konu önemsiz olduğunda veya çatışmanın devamında her iki tarafında zarar görmesinin söz konusu olabileceği durumunda faydalıdır (Rahim ve Bonoma, 1979). Kaçınma davranışı meseleyi daha iyi bir zamana kadar erteleme ya da tehdit edici bir durumdan çekilme biçiminde kullanılabilir (Rahim, 2001). Bu stil, bazı taktik veya küçük sorunlarla baş etmek için kullanılabilir (Rahim, 1985). Son boyut olan (5)Uzlaşma Stili ise çatışma taraflarının her ikisinin de bir şeylerden vazgeçerek kabul edilebilir bir karar vermesi durumudur (Rahim, 2001). Uzlaşma stilinde her iki tarafında kazançlı çıkması söz konusudur. Çatışan tarafların her ikisinin de eşit derecede güçlü olduğunda köklü zararlar ortaya çıkarmadan çözüme ulaşılabileceği için faydalıdır (Rahim ve Bonoma, 1979). Çatışma taraflarının düşüncelerinin kişilere özgü olduğu durumlarda tarafların daha uç noktalara ayrışarak yıkıcı sonuçlar oluşturmadan kullanmaları gereken bir stildir (Rahim, 1985).

Örgütlerde oluşan çatışmalar örgüt sağlığı için her zaman olumsuz sonuç vermez. Çatışmalar iyi yönetilmesi durumunda örgütün sağlığı ve gelişimi açısından büyük önem kazanır. Örgütlerdeki çatışmalar iyi yönetildiğinde (Eren, 2016); (1)çatışma sonucunda ortaya orijinal fikirlerin ortaya çıkması sağlanacaktır; (2)tarafların çatışma konusuna ilişkin araştırma eğilimleri artacaktır; (3)bireysel ve örgütsel sorunlar incelenerek bu sorunların çözümü ile ilgili sonuç elde edilecek ve gerilim azaltılmış olacaktır; (4)bireyler sorunların çözümü ile ilgili düşünce ve fikirlerini açıklayacaklardır; (5)örgütsel etkililiği olumsuz etkileyen sorunlar ortadan kalkacaktır; (6)çatışan taraflar kendi bilgi ve yeteneklerini değerlendirme fırsatı bulacaklardır. Yukarıda da açıklanan çatışma durumlarının iyi yönetilmesi durumunda örgütlerde oluşacak olumlu durumlar düşünüldüğünde yöneticilerin çatışma durumlarında kullandıkları çatışma yönetim stilleri ile örgütlerin sağlıklı bir şekilde yaşamlarını sürdürebilmeleri arasında önemli bir ilişki olabileceği düşünülmektedir. Bu nedenle bu araştırmada okul yöneticilerinin kullandıkları çatışma yönetim stilleri ile okulların örgüt sağlığı arasındaki ilişkinin incelenmesi amaçlanmaktadır. Bu temel amaç doğrultusunda aşağıdaki sorulara yanıt aranmıştır:

1. Öğretmenlerin okulların örgüt sağlığına ve okul yöneticilerinin kullandıkları çatışma yönetim stillerine ilişkin algıları nelerdir?

2. Okulların örgüt sağlığı düzeyleri öğretmenlerin cinsiyetlerine ve çalıştıkları okul kademesine göre farklılık göstermekte midir?

3. Öğretmenlerin okul yöneticilerinin kullandıkları çatışma yönetim stili algıları cinsiyetlerine ve çalıştıkları okul kademesine göre farklılık göstermekte midir?

4. Okul yöneticilerinin kullandıkları çatışma yönetim stilleri ile okulların örgüt sağlığı düzeyleri arasında ilişki var mıdır?

5. Okul yöneticilerinin kullandığı çatışma yönetim stilleri okulların örgüt sağlığı düzeylerini yordamakta mıdır? 


\section{Araştırma Modeli}

\section{Yöntem}

Eğitim örgütlerindeki yöneticilerin kullandıkları çatışma yönetim stilleri ile örgüt sağlığı arasındaki ilişkiyi ölçmeyi amaçlayan araştırma, ilişkisel tarama modelindedir. Tarama modelleri, geçmişte olan ya da günümüzde var olmaya devam eden bir durumu var olduğu şekilde betimlemeyi amaçlayan araştırma modelidir. Araştırmaya konu olan olay, birey ya da nesne, kendi koşulları içinde var olduğu şekilde tanımlanmaya çalışılmaktadır. İlişkisel tarama modeli, iki ve daha fazla sayıdaki değişken arasında birlikte değişimin varlığını ve/veya derecesini tanımlamayı amaçlayan araştırma modelidir. Korelasyon ve karşılaştırmalı tarama modeli olmak üzere iki türü vardır. Bu araştırmada kullanılan karşılaştırma yolu ile ilişki belirlemede, en az iki değişken olmalı ve bunlardan birine (sınanmak istenen bağımsız değişkene) göre gruplar oluşturulur, öteki (bağımlı) değişkene göre aralarında bir farklılaşma olup olmadığı incelenir (Karasar, 2016). Bu çalışmada da okul yöneticilerinin kullandıkları çatışma yönetim stilleri bağımsız, örgütsel sağlık bağımlı değişken olarak ele alınmıştır.

\section{Evren ve Örneklem}

Araştırmanın evreni 2017-2018 eğitim öğretim yılında Uşak ilindeki kamuya ait ilkokul, ortaokul ve liselerde görev yapmakta olan 3986 öğretmenden oluşmaktadır. Örneklem seçiminde kuramsal örneklem büyüklüğü çizelgesinden yararlanılmıştır (Balcı, 2013). Belirlenen örneklem büyüklüğüne göre örneklemin belirlenmesinde basit tesadüfî örnekleme yöntemi kullanılmıştır. Araştırmanın örneklemini oluşturan 349 öğretmenin 123'ü (\%35.24) ilkokulda, 136'sı (\%38.97) ortaokulda, 90'ı (\%25.79) ise lisede görev yapmaktadır.

\section{Veri Toplama Araçları}

$\mathrm{Bu}$ çalışmada okul yöneticilerinin kullandıkları çatışma yönetim stillerini belirlemek için Rahim tarafından geliştirilen "Rahim Örgütsel Çatışma Anketi" B Formu'nun Gümüşeli (1994) tarafından Türkçe' ye uyarlanan "Çatışma Yönetim Stilleri Ölçeği” kullanılmıştır. Araştırmada kullanılan bir diğer veri toplama aracı, Akbaba (1997) tarafından geliştirilen "Örgüt Sağlığı Ölçeği"dir.

Çatışma Yönetim Stilleri Ölçeği: Rahim tarafından geliştirilen "Rahim Örgütsel Çatışma Anketi" B Formu'nun Gümüşeli (1994) tarafından Türkçe' ye uyarlanan "Çatışma Yönetim Stilleri Ölçeği" kullanılmıştır. Türkçe ölçeğin Cronbach Alfa güvenirlik değeri. 88 olarak belirlenmiştir (Gümüşeli, 1994). Bu çalışma için hesaplanan Cronbach Alfa korelasyon katsayısı ise .83 olarak tespit edilmiştir. Ölçek 5 boyut ve 28 maddeden oluşmuştur. Bu boyutlar; (1) Tümleştirme, (2) Ödün Verme (3) Hükmetme (4) Kaçınma (5) Uzlaşma' dır.

Örgüt Sağlığı Ölçeği: Akbaba (1997) tarafından geliştirilen "Örgüt Sağlığı Ölçeği"dir. Ölçek beş boyut ve 53 maddeden oluşmaktadır. Bu boyutlar; (1) Örgütsel Liderlik, (2) Örgütsel Bütünlük, (3) Örgütsel Kimlik, (4) Örgütsel Ürün ve (5) Çevresel Etkileşim'dir. Ölçeğin formunun iç tutarlık katsayısının belirlenmesi için Cronbach Alfa korelasyon katsayısı hesaplanmıştır. Yapılan analiz sonucunda ölçeğin tamamına 
ilişkin güvenirlik katsayısı .95 olarak belirlenmiştir (Akbaba, 1997). Bu çalışma için hesaplanan Cronbach Alfa korelasyon katsayısı ise .96 olarak tespit edilmiştir.

\section{Verilerin Analizi}

Araştırmada, kullanılacak veri analiz tekniklerinin belirlenmesi için öncelikle verilerin normal dağılım gösterip göstermediğine bakılmıştır. Bunun için çarpıklık ve basıklık değerlerine bakılmıştır. Karagöz' e (2016) göre verilerin normal dağılım gösterdiğinin kabul edilmesi için çarpıklık ve basıklık değerleri +2 ile -2 değerleri arasında olmalıdır. Bu çalışma için elde edilen çarpıklık ve basıklık katsayıları kabul gören değerler arasında olması nedeniyle analizde normal dağılım testleri uygulanmıştır. Elde edilen çarpıklık ve basıklık katsayıları Tablo 1' de verilmiştir. Verilerin analizinde t-Testi, ANOVA, Pearson korelasyon katsayısı ve basit doğrusal regresyon analizi kullanılmıştır. ANOVA testi sonucunda anlamlı farklılık olan boyutlarda farkın hangi gruplardan kaynaklandığını bulmak için Tukey testi sonuçlarına bakılmıştır. Bulguları yorumlamada kullanılan ortalama aralıkları 1.001.80 çok düşük, 1.81-2.60 düşük, 2.61-3.40 orta, 3.41-4.20 yüksek ve 4.21-5.00 çok yüksek şeklinde yorumlanmıştır.

\section{Bulgular}

Tablo 1. Öğretmenlerin Okul Yöneticilerinin Kullandıkları Çatışma Yönetim Stillerine ve Çalıştıkları Okulun Örgüt Sağlığına Yönelik Algı Düzeylerine İlişkin Betimsel İstatistikler Ve Normallik Analizi Sonuçları

X Ss Çarpıklık Basıklık

\begin{tabular}{|c|c|c|c|c|}
\hline \multicolumn{5}{|c|}{ Çatışma Yönetim Stilleri Ölçeği } \\
\hline Tümleştirme & 3.09 & .69 & -.936 & 1.532 \\
\hline Ödün verme & 3.54 & .68 & -.359 & .641 \\
\hline Hükmetme & 2.38 & .87 & .352 & -.519 \\
\hline Kaçınma & 3.25 & 1.07 & -.669 & -.707 \\
\hline Uzlaşma & 4.01 & .66 & -.788 & 1.052 \\
\hline \multicolumn{5}{|l|}{ Örgüt Sağlığı Ölçeği } \\
\hline Örgütsel Liderlik & 4.25 & .59 & -1.053 & 1.790 \\
\hline Örgütsel Bütünlük & 4.06 & .61 & -.866 & 1.007 \\
\hline Örgütsel Kimlik & 4.11 & .54 & -.581 & 1.153 \\
\hline Örgütsel Ürün & 4.14 & .52 & -.596 & 1.070 \\
\hline Çevresel Etkileşim & 4.03 & .53 & -.310 & -.151 \\
\hline Toplam (Örgüt Sağlığı) & 4.12 & .50 & -.771 & 1.270 \\
\hline
\end{tabular}


Tablo 1' e göre öğretmenler okul yöneticilerinin çatışma yönetim stillerinden "Hükmetme" boyutunda düşük düzeyde; "Tümleştirme" ve "Kaçınma" boyutlarında orta düzeyde; "Ödün verme" ve "Uzlaşma" boyutlarında yüksek düzeyde davranışlar sergilediklerini düşünmektedirler. Öğretmenlerin okulların örgütsel sağlıklarına yönelik görüşlerine bakıldığında ise öğretmenler genel olarak, okulların yüksek düzeyde sağlıklı örgütler olduğunu düşünmektedirler. Öğretmenlerin örgüt sağlığının boyutlarından "Örgütsel liderlik" boyutuna yönelik algılarının çok yüksek düzeyde; "Örgütsel Bütünlük", "Örgütsel Kimlik", "Örgütsel Ürün” ve "Çevresel Etkileşim" boyutlarına yönelik algılarının yüksek düzeyde olduğu görülmektedir.

Tablo 2. Öğretmenlerin Cinsiyetlerine Göre Çatışma Yönetim Stilleri ve Örgüt Sağlığı Algısı

\begin{tabular}{|c|c|c|c|c|c|c|c|}
\hline Değişken & Cinsiyet & $\mathbf{N}$ & $\mathbf{x}$ & Ss & $t$ & Sd & $\mathbf{p}$ \\
\hline \multicolumn{8}{|c|}{ Çatışma Yönetim Stilleri Ölçeği } \\
\hline \multirow{2}{*}{ Tümleştirme } & Kadın & 176 & 4.09 & 0.70 & \multirow{2}{*}{.288} & \multirow{2}{*}{347} & \multirow{2}{*}{0.77} \\
\hline & Erkek & 173 & 4.07 & 0.68 & & & \\
\hline \multirow{2}{*}{ Ödün verme } & Kadın & 176 & 3.55 & 0.73 & \multirow{2}{*}{.391} & \multirow{2}{*}{347} & \multirow{2}{*}{0.69} \\
\hline & Erkek & 173 & 3.42 & 0.61 & & & \\
\hline \multirow{2}{*}{ Hükmetme } & Kadın & 176 & 2.23 & 0.82 & \multirow{2}{*}{-3.524} & \multirow{2}{*}{347} & \multirow{2}{*}{0.00} \\
\hline & Erkek & 173 & 2.55 & 0.88 & & & \\
\hline \multirow{2}{*}{ Kaçınma } & Kadın & 176 & 3.28 & 1.10 & \multirow{2}{*}{.534} & \multirow{2}{*}{347} & \multirow{2}{*}{0.59} \\
\hline & Erkek & 173 & 3.22 & 1.05 & & & \\
\hline \multirow{2}{*}{ Uzlaşma } & Kadın & 176 & 4.09 & 0.64 & \multirow{2}{*}{2.171} & \multirow{2}{*}{346} & \multirow{2}{*}{0.03} \\
\hline & Erkek & 173 & 3.93 & 0.67 & & & \\
\hline \multicolumn{8}{|l|}{ Örgüt Sağlığı Ölçeği } \\
\hline \multirow{2}{*}{ Örgütsel Liderlik } & Kadın & 176 & 4.27 & 0.59 & \multirow{2}{*}{.921} & \multirow{2}{*}{347} & \multirow{2}{*}{0.35} \\
\hline & Erkek & 173 & 4.21 & 0.60 & & & \\
\hline \multirow{2}{*}{ Örgütsel Bütünlük } & Kadın & 176 & 4.08 & 0.60 & \multirow{2}{*}{.667} & \multirow{2}{*}{347} & \multirow{2}{*}{0.50} \\
\hline & Erkek & 173 & 4.04 & 0.61 & & & \\
\hline \multirow{2}{*}{ Örgütsel Kimlik } & Kadın & 176 & 4.11 & 0.52 & \multirow{2}{*}{.003} & \multirow{2}{*}{347} & \\
\hline & Erkek & 173 & 4.11 & 0.56 & & & 0.99 \\
\hline Öraütsel Ürün & Kadın & 176 & 4.14 & 0.52 & & & \\
\hline Urgutsel Urun & Erkek & 173 & 4.13 & 0.52 & .163 & 347 & 0.87 \\
\hline & Kadın & 176 & 4.08 & 0.53 & & & \\
\hline Çevresel Etkıleşım & Erkek & 173 & 3.98 & 0.52 & 1.615 & $34 t$ & 0.10 \\
\hline Toplam (Öraüt Saălıăı) & Kadın & 176 & 4.14 & 0.49 & 907 & 347 & 0.36 \\
\hline 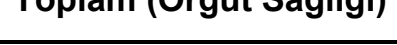 & Erkek & 173 & 4.09 & 0.50 & .501 & $04 t$ & 0.00 \\
\hline
\end{tabular}

Tablo 2' de yer alan bulgular incelendiğinde, cinsiyet değişkenine göre öğretmenlerin çatışma yönetim stili algıları hükmetme ve uzlaşma boyutlarında anlamlı farklılık gösterirken $(p<0.05)$; tümleştirme, ödün verme ve kaçınma boyutlarında anlamlı farklılık göstermemektedir $(p>0.05)$. Erkek öğretmenler kadın öğretmenlere göre okul yöneticilerinin çatışma durumlarında daha az uzlaşmacı olduklarını ve çatışmaları yönetmek için daha çok hükmetme stilini kullandıklarını düşünmektedirler. Öğretmenlerin cinsiyet değişkenine göre örgüt sağlığı algıları incelendiğinde, örgüt sağlığının tümünde ve tüm alt boyutlarında cinsiyet değişkenine göre öğretmen algılarında anlamlı bir farklııı olmadığı görülmektedir( $p>0.05)$. 
Tablo 3. Okul Kademelerine Göre Öğretmenlerin Çatışma Yönetim Stili Algılarına İlişkin Varyans Analizi Sonuçları

\begin{tabular}{|c|c|c|c|c|c|c|c|}
\hline Değişken & $\begin{array}{l}\text { Okul } \\
\text { Kademesi }\end{array}$ & $\mathbf{N}$ & $\mathbf{X}$ & Ss & $\mathbf{F}$ & $\mathbf{p}$ & Fark \\
\hline \multicolumn{8}{|c|}{ Çatışma Yönetim Stilleri Ölçeği } \\
\hline \multirow{3}{*}{ Tümleştirme } & İlkokul(A) & 123 & 4.14 & 0.063 & \multirow{3}{*}{1.31} & \multirow{3}{*}{0.27} & \multirow{3}{*}{ Yok } \\
\hline & Ortaokul(B) & 136 & 4.09 & 0.068 & & & \\
\hline & Lise $(\mathrm{C})$ & 90 & 3.99 & 0.050 & & & \\
\hline \multirow{3}{*}{ Ödün verme } & İlkokul(A) & 123 & 3.52 & 0.063 & \multirow{3}{*}{2.46} & \multirow{3}{*}{0.08} & \multirow{3}{*}{ Yok } \\
\hline & Ortaokul(B) & 136 & 3.46 & 0.065 & & & \\
\hline & Lise $(\mathrm{C})$ & 90 & 3.66 & 0.051 & & & \\
\hline \multirow{3}{*}{ Hükmetme } & İlkokul(A) & 123 & 2.11 & 0.072 & \multirow{3}{*}{14.90} & \multirow{3}{*}{0.00} & A-B \\
\hline & Ortaokul(B) & 136 & 2.40 & 0.078 & & & $\mathrm{~B}-\mathrm{C}$ \\
\hline & Lise $(\mathrm{C})$ & 90 & 2.75 & 0.080 & & & $\mathrm{~A}-\mathrm{C}$ \\
\hline \multirow{3}{*}{ Kaçınma } & İlkokul(A) & 123 & 3.21 & 0.097 & \multirow{3}{*}{1.23} & \multirow{3}{*}{0.29} & \multirow{3}{*}{ Yok } \\
\hline & Ortaokul(B) & 136 & 3.18 & 0.096 & & & \\
\hline & Lise(C) & 90 & 3.40 & 0.104 & & & \\
\hline \multirow{3}{*}{ Uzlaşma } & İlkokul(A) & 123 & 4.19 & 0.054 & \multirow{3}{*}{10.31} & \multirow{3}{*}{0.00} & \multirow{3}{*}{$\begin{array}{l}\text { A-C } \\
B-C\end{array}$} \\
\hline & Ortaokul(B) & 136 & 4.01 & 0.066 & & & \\
\hline & Lise $(\mathrm{C})$ & 90 & 3.78 & 0.051 & & & \\
\hline
\end{tabular}

Tablo 3 incelendiğinde öğretmenlerin çalıştıkları okul kademesi değişkenine göre okul yöneticilerinin kullandıkları çatışma yönetim stili algılarında, tümleştirme, ödün verme ve kaçınma boyutlarında anlamlı farklılık olmadığı görülürken ( $p>0.05)$; hükmetme ve uzlaşma boyutlarında anlamlı farklılık olduğu görülmektedir $(p<0.05)$. Liselerde çalışan öğretmenler, ilkokul ve ortaokullarda çalışan öğretmenlere göre okul yöneticilerinin çatışma durumlarında daha fazla hükmetme stilini kullandıklarını ve çatışma durumlarında daha az uzlaşmacı davrandıklarını düşünmektedirler. İlkokullardaki öğretmenler ise lise ve ortaokullarda çalışan öğretmenlere göre okul yöneticilerinin çatışma durumlarında daha az hükmetme stilini kullandıklarını düşünmektedirler.

Tablo 4. Okul Kademelerine Göre Öğretmenlerin Örgüt Sağlığı Algılarına İlişkin Varyans Analizi Sonuçları

\begin{tabular}{|c|c|c|c|c|c|c|c|}
\hline Değişken & $\begin{array}{l}\text { Okul } \\
\text { Kademesi }\end{array}$ & $\mathbf{N}$ & $\mathbf{x}$ & Ss & $\mathbf{F}$ & $\mathbf{p}$ & Fark \\
\hline \multicolumn{8}{|l|}{ Örgüt Sağlığı Ölçeği } \\
\hline \multirow{3}{*}{ Örgütsel Liderlik } & İlkokul(A) & 123 & 4.32 & 0.546 & \multirow{3}{*}{2.52} & \multirow{3}{*}{0.08} & \multirow{3}{*}{ Yok } \\
\hline & Ortaokul(B) & 136 & 4.25 & 0.699 & & & \\
\hline & Lise $(\mathrm{C})$ & 90 & 4.13 & 0.490 & & & \\
\hline \multirow{3}{*}{ Örgütsel Bütünlük } & İlkokul(A) & 123 & 4.14 & 0.595 & \multirow{3}{*}{1.57} & \multirow{3}{*}{0.20} & \multirow{3}{*}{ Yok } \\
\hline & Ortaokul(B) & 136 & 4.01 & 0.696 & & & \\
\hline & Lise $(\mathrm{C})$ & 90 & 4.04 & 0.468 & & & \\
\hline \multirow{3}{*}{ Örgütsel Kimlik } & İlkokul(A) & 123 & 4.15 & 0.494 & \multirow{3}{*}{0.55} & \multirow{3}{*}{0.57} & \multirow{3}{*}{ Yok } \\
\hline & Ortaokul(B) & 136 & 4.07 & 0.606 & & & \\
\hline & Lise $(\mathrm{C})$ & 90 & 4.11 & 0.518 & & & \\
\hline
\end{tabular}


Tablo 4'ün devamı

\begin{tabular}{|c|c|c|c|c|c|c|c|}
\hline \multirow{3}{*}{ Örgütsel Ürün } & İlkokul(A) & 123 & 4.14 & 0.563 & \multirow{3}{*}{0.08} & \multirow{3}{*}{0.92} & \multirow{3}{*}{ Yok } \\
\hline & Ortaokul(B) & 136 & 4.12 & 0.534 & & & \\
\hline & Lise $(\mathrm{C})$ & 90 & 4.15 & 0.436 & & & \\
\hline \multirow{3}{*}{ Çevresel Etkileşim } & İlkokul(A) & 123 & 4.10 & 0.523 & \multirow{3}{*}{1.87} & \multirow{3}{*}{0.15} & \multirow{3}{*}{ Yok } \\
\hline & Ortaokul(B) & 136 & 4.00 & 0.540 & & & \\
\hline & Lise(C) & 90 & 3.98 & 0.528 & & & \\
\hline \multirow{3}{*}{$\begin{array}{l}\text { Toplam } \\
\text { Sağlığı) }\end{array}$} & İlkokul(A) & 123 & 4.17 & 0.492 & \multirow{3}{*}{1.36} & \multirow{3}{*}{0.25} & \multirow{3}{*}{ Yok } \\
\hline & Ortaokul(B) & 136 & 4.09 & 0.561 & & & \\
\hline & Lise(C) & 90 & 4.07 & 0.392 & & & \\
\hline
\end{tabular}

Tablo 4'de yer alan bulgulara göre öğretmenlerin çalıştıkları okul kademesi değişkenine göre örgüt sağlığının tamamında ve tüm alt boyutlarında anlamlı farklılık bulunmamaktadır ( $p>0.05$ ). Öğretmenlerin örgüt sağı̆ğı algıları çalıştıkları okul kademesi değişkenine göre değişmediği görülmektedir. Buna göre öğretmenlerin çalıştıkları okul kademesi ne olursa olsun okulun örgüt sağlığı düzeyini aynı ya da benzer düzeyde gördükleri sonucu çıkarılabilir.

Tablo 5. Okul Yöneticilerinin Kullandığı Çatışma Yönetim Stilleri İle Örgüt Sağlığı Arasındaki İlişkiyi Gösteren Korelasyon Analizi Sonuçları

\begin{tabular}{lccccc}
\hline & \multicolumn{5}{c}{ Çatışma Yönetim Stilleri } \\
\hline & Tümleştirme & $\begin{array}{l}\text { Ödün } \\
\text { Verme }\end{array}$ & Hükmetme & Kaçınma & Uzlaşma \\
\hline Örgütsel Liderlik & $.841^{* *}$ & $.574^{* *}$ & $-.326^{* *}$ & $.143^{* *}$ & $.759^{* *}$ \\
\hline Örgütsel Bütünlük & $.724^{* *}$ & $.527^{* *}$ & $-.446^{* *}$ & .079 & $.713^{* *}$ \\
\hline Örgütsel Kimlik & $584^{* *}$ & $.445^{* *}$ & -.015 & .038 & $.480^{* *}$ \\
\hline Örgütsel Ürün & $.665^{* *}$ & $.526^{* *}$ & $-.124^{*}$ & .072 & $.580^{* *}$ \\
\hline Çevresel Etkileşim & $.700^{* *}$ & $.498^{* *}$ & $-.259^{* *}$ & .063 & $.647^{* *}$ \\
\hline Toplam(Örgüt Sağlığı) & $.814^{* *}$ & $.588^{* *}$ & $-.294^{* *}$ & .096 & $.743^{* *}$ \\
\hline$* *$
\end{tabular}

${ }^{* *}$ Korelasyon $\mathrm{p}<0.01$ düzeyinde anlamlıdır * Korelasyon $\mathrm{p}<0.05$ düzeyinde anlamlıdır.

Korelasyon, iki değişken arasında anlamlı bir ilişki olup olmadığını belirlemek için kullanılan bir analiz tekniğidir. Korelasyon katsayısı 1.00 ile -1.00 arasında değişmektedir. 1.00 olması mükemmel pozitif bir ilişkiyi, -1.00 olması mükemmel negatif bir ilişkiyi gösterir. Korelasyon katsayısının mutlak değer olarak 0.70-1.00 arasında olması yüksek, 0.30-0.70 arasında olması orta, 0.00-0.30 arasında olması düşük düzeyde ilişki olduğu anlamına gelmektedir (Büyüköztürk, 2012). Buna göre Tablo 5'ten de anlaşılacağı üzere; okul yöneticilerinin kullandığı çatışma yönetim sitilleri ile öğretmenlerin örgüt sağlığı algıları arasındaki ilişkiyi ölçmek için yapılan korelasyon analizine göre şu bulgulara ulaşılmıştır. Örgüt sağlığının örgütsel liderlik boyutu ile okul yöneticilerinin kullandığı çatışma yönetim stillerinden tümleştirme ve uzlaşma stilleri arasında pozitif yönde yüksek dereceli; ödün verme stili ile arasında pozitif yönde orta dereceli; hükmetme stili ile arasında negatif yönde orta dereceli; kaçınma stili ile arasında pozitif yönde düşük düzeyde ilişki olduğu görülmektedir. Örgüt sağlığının diğer boyutu olan örgütsel bütünlük boyutu ile okul yöneticilerinin kullandığı çatışma yönetim stillerinden tümleştirme ile uzlaşma stilleri ile arasında pozitif yönde yüksek dereceli ilişki; ödün verme stili ile arasında pozitif yönde orta dereceli; hükmetme stili ile negatif yönde orta dereceli bir ilişki olduğu görülürken; 
kaçınma stili ile aralarındaki ilişkinin anlamlı olmadığı görülmüştür. Örgüt sağlığının bir başka boyutu olan örgütsel kimlik ile okul yöneticilerinin kullandığı çatışma yönetim stillerinden tümleştirme, ödün verme ve uzlaşma stilleri ile arasında pozitif yönde orta dereceli bir ilişki olduğu görülürken; hükmetme ve kaçınma stilleri ile arasındaki ilişkinin anlamlı olmadığı tespit edilmiştir. Örgüt sağlığının bir diğer boyutu olan örgütsel ürün ile okul yöneticilerinin kullandığı çatışma yönetim stillerinden tümleştirme, ödün verme ve uzlaşma stilleri ile arasında pozitif yönde orta dereceli; hükmetme stili ile negatif yönde düşük dereceli bir ilişki olduğu görülürken; kaçınma stili ile arasındaki ilişkinin anlamlı olmadığı görülmüştür. Örgüt sağlığının son boyutu olan çevresel etkileşim boyutu ile okul yöneticilerinin kullandığı çatışma yönetim stillerinden tümleştirme, ödün verme ve uzlaşma stilleri ile arasında pozitif yönde orta dereceli; hükmetme stili ile negatif yönde düşük dereceli bir ilişki olduğu görülürken; kaçınma stili ile arasındaki ilişkinin anlamlı olmadığı görülmüştür. Örgüt sağlığının boyutları ile çatışma yönetim stilleri arasındaki ilişki incelendiğinde sonuç olarak örgüt sağlığının örgütsel kimlik, örgütsel ürün ve çevresel etkileşim boyutları ile çatışma yönetim stillerinden tümleştirme, ödün verme ve uzlaşma stilleri ile arasında pozitif yönde orta dereceli bir ilişki olduğu görülürken; kaçınma stili ile arasındaki ilişkinin anlamlı olmadığı görülmüştür.

Öğretmen algılarına göre örgüt sağlığının toplamı ile okul yöneticilerinin kullandığı çatışma yönetim stilleri arasındaki ilişkiye yönelik bulgulara bakıldığında ise; çatışma yönetim stillerinden tümleştirme ve uzlaşma stilleri ile örgüt sağlığı arasında pozitif yönde yüksek derecede; ödün verme stili ile örgüt sağlığı arasında pozitif yönde orta derecede; hükmetme stili ile örgüt sağlığı arasında negatif yönde düşük dereceli bir ilişki olduğu görülürken; kaçınma stili ile örgüt sağlığı arasındaki ilişkinin anlamlı olmadığı görülmektedir.

Tablo 6. Okul Yöneticilerinin Kullandıkları Çatışma Yönetim Stillerinin Örgüt Sağlığını Yordamasına İlişkin Regresyon Sonuçları

Yordanan değişken: Örgüt sağlığı

\begin{tabular}{|c|c|c|c|c|c|}
\hline Yordayıcı Değişken & B & $\begin{array}{l}\text { Standart } \\
\text { Hata }\end{array}$ & $\beta$ (Beta) & $\mathbf{t}$ & $\mathbf{p}$ \\
\hline Sabit & 1.549 & .142 & & 10.942 & .00 \\
\hline Tümleştirme & .411 & .045 & .570 & 9.215 & .00 \\
\hline Ödün verme & .066 & .032 & .090 & 2.063 & .04 \\
\hline Hükmetme & .012 & .021 & .021 & .557 & .58 \\
\hline Kaçınma & -.021 & .015 & -.045 & -1.391 & .17 \\
\hline Uzlaşma & .175 & .046 & .234 & 3.825 & .00 \\
\hline $\mathbf{R}^{2}=.679$ & & & & & \\
\hline $\mathbf{F}(5.342)=144.72 \quad \mathbf{P}<.05$ & & & & & \\
\hline
\end{tabular}

Regresyon analizi sonuçlarının yer aldığı Tablo 6 incelendiğinde okul yöneticilerinin kullandığı çatışma yönetim stillerinden tümleştirme, ödün verme ve uzlaşma stilleri, örgüt sağlığını anlamlı şekilde yordadığı görülmektedir. Okul yöneticilerinin kullandıkları çatışma yönetim stilleri, okulların örgüt sağlığındaki 
varyansın yaklaşık \%67' sini açıklamaktadır ( $\left.R=824, R^{2}=.679, p<.05\right)$. Çatışma yönetim stillerinin örgüt sağlığını açıklamadaki etkileri incelenecek olursa, tümleştirme boyutunun etkisi en yüksektir $(\beta=.57)$. Çatışma yönetim stillerinden tümleştirme boyutundaki bir birimlik artış örgüt sağlığı üzerinde 0.57 birimlik artışa; ödün verme boyutundaki bir birimlik artış örgüt sağlığı üzerinde 0.09 birimlik artışa; uzlaşma boyutundaki bir birimlik artış örgüt sağlığı üzerinde 0.234 birimlik artışa neden olduğu görülmektedir.

\section{Sonuç ve Tartışma}

$\mathrm{Bu}$ araştırma okul yöneticilerinin okullarda meydana gelen çatışmalarda kullandıkları çatışma yönetim stilleri ile okulların örgütsel sağlığı arasındaki ilişkiyi ölçmeyi amaçlamaktadır. Araştırmada elde edilen sonuçlara göre öğretmenler genel olarak yüksek düzeyde okul yöneticilerinin çatışma durumlarında ödün verme ve uzlaşma stillerini kullandıklarını düşünmektedirler. Uzlaşma stilinde taraflarının her ikisi de çatışmayı çözüme ulaştırabilmek için arzu ettiklerinin veya sahip olduklarının bir kısmından vazgeçerek ortak noktayı bulma çabasındayken (Rahim, 2001); ödün verme stilinde çatışma taraflarından biri kendi taleplerinden vazgeçerek karşısındakinin ilgi ve intiyaçlarını ön plana çıkarmaktadır (Karip, 1999). Çatışma yönetim stillerinin diğer boyutlarından tümleştirme ve kaçınma stillerini orta düzeyde; hükmetme stilini ise düşük düzeyde kullandıklarını düşünmektedirler. Ural (1997), Uğurlu (2001), Şendur (2006) ve Toytok ve Açıkgöz (2013), Koçak ve Baskan (2013) Önk (2015), tarafında yapılan çalışmalarda da öğretmenler okul yöneticilerinin çatışma durumlarında en az tercih ettikleri çatışma yönetim stilinin hükmetme stilinin olduğunu ifade etmektedirler. Hükmetme stili daha çok yetkici bir yönetim anlayışını ifade etmektedir (Karip, 1999). Egemen kişinin konum gücünü kullanarak kendi düşüncelerini karşı tarafa kabul ettirmek için zorlayıcı olmasıdır (Rahim, 2001). Bu durumda yetkici bir anlayış olarak nitelendirilen hükmetme stilinin yöneticiler tarafında sıkça kullanılması okulların örgüt sağlığını olumsuz etkileyeceği söylenebilir. Ancak çatışmaya konu olan meselelerin önemsiz olduğunda ve hızlı karar verilmesi gerektiğinde hükmetme stilinin kullanılmasının uygun olması (Rahim ve Bonoma, 1979) nedeniyle, örgütsel hedeflere ulaşabilmede yöneticilerin karar verme süreçlerinde dikkatli bir şekilde tercih etmeleri gereken bir stil olarak nitelendirilebilir.

Cinsiyet ve okul kademesi değişkenlerine göre okul yöneticilerinin kullandıkları çatışma yönetim stillerinden tümleştirme, ödün verme ve kaçınma boyutlarında anlamlı farklılık bulunmamış; yine aynı değişkenlere göre hükmetme ve uzlaşma boyutlarında gruplar arasında anlamlı farklılık olduğu tespit edilmiştir. Kadın öğretmenler erkek öğretmenlere okul yöneticilerinin çatışma durumlarında daha çok uzlaşmacı davrandıklarını düşünürken, erkek öğretmenler kadın öğretmenlere göre okul yöneticilerinin çatışma durumlarında daha çok karşısındakinin ihtiyaçlarını yok sayarak hükmetme davranışları sergilediklerini düşünmektedirler. Kırçan ve Bostancı (2012) tarafından yapılan çalışmada da cinsiyet değişkenine göre okul yöneticilerinin kullandıkları çatışma yönetim stillerinden hükmetme boyutunda gruplar arasında anlamlı farklılık olduğu görülmüştür. Tanrıverdi (2008) tarafından yürütülen bir diğer çalışmada ise çatışma yönetim stillerinden hükmetme boyutunda kadın ve erkek 
öğretmen algıları arasında anlamlı farklılık olduğu tespit edilmiş ve bu çalışmayla paralel olarak erkek öğretmenlerin okul yöneticilerinin çatışma durumlarında kadın öğretmenlere göre daha çok hükmetme stilini kullandıklarını düşünmektedirler. Ayrıca çalışmamamızda elde edilen bir diğer sonuç ise liselerde görev yapan öğretmenler araştırmada ele alınan diğer okul kademelerindeki öğretmenlere göre okul yöneticilerinin çatışma durumlarında daha fazla hükmetme stilini kullandıklarını ve daha az düzeyde uzlaşmacı davrandıklarını düşünmektedirler. Buna göre liselerde görev yapan öğretmenler okul yöneticilerinin orta düzeyde hükmetme stilini kullandıklarını düşünmektedirler. Çalışmadaki bu sonuca paralel olarak Tanrıverdi tarafından 2008 yılında liselerde görev yapan öğretmenlerin okul yöneticilerinin kullandıkları çatışma yönetim stili algılarını belirlemeye yönelik çalışmasında da liselerde görev yapan öğretmenlerin okul yöneticilerinin orta düzeyde hükmetme stilini kullandıkları görülmüştür.

Araştırmanın örgüt sağlığı değişkenine yönelik sonuçlara bakıldığında ise, öğretmenler genel olarak, okulların yüksek düzeyde sağlıklı örgütler olduğunu düşünmektedirler. Taneri (2011), Ayduğ ve Ağaoğlu (2014) da çalışmalarında öğretmenlerinin okullarının örgüt sağlığını yüksek düzeyde değerlendirirken, Özdemir (2006) tarafından İzmir ili Bornova ilçesinde bulunan ilköğretim okullarında yürütülen çalışmada ve Buluç' un (2008) ortaöğretim okullarında yürütülen çalışmada ise öğretmenlerin örgüt sağlığına ilişkin algılarının orta düzeyde olduğu görülmektedir. Öğretmenlerin örgüt sağıı̆ının boyutlarına yönelik algılarına bakıldığında, örgütsel liderlik boyutuna yönelik algılarının çok yüksek düzeyde olduğu, örgüt sağlığının diğer boyutları olan örgütsel bütünlük, örgütsel kimlik, örgütsel ürün ve çevresel etkileşim boyutlarına yönelik algılarının yüksek düzeyde olduğu görülmektedir.

Cinsiyet ve okul kademesi değişkenlerine göre öğretmenlerin örgüt sağlığı algıları incelendiğinde, örgüt sağlığının tümünde ve tüm alt boyutlarında gruplar arasında anlamlı farklılık olmadığı görülmektedir. Araştırma sonuçlarına paralel olarak Akbaba (1997), Özdemir (2006), Edwards (2008), Ebcim (2012) ve Ayduğ (2014) tarafından yapılan çalışmalarda da öğretmenlerin cinsiyet değişkenine göre örgüt sağlığının tamamındaki algılarında anlamlı bir farklılık bulunmadığı görülmektedir. Çoban (2007) ilköğretim öğretmenlerinin algılarına dayalı olarak yapmış olduğu çalışmada ise cinsiyet değişkenine göre örgüt sağlığının sadece örgütsel kimlik boyutunda erkek öğretmenler ile kadın öğretmenler arasında anlamlı farklılık olduğu tespit edilmiştir.

Araştırmada okul yöneticilerinin okullarda meydana gelen çatışmalarda kullandıkları çatışma yönetim stilleri ile okulların örgütsel sağlığı arasında bir ilişki olup olmadığına yönelik ulaşılan sonuçlara göre, okul yöneticilerinin çatışmaları yönetmek için tümleştirme ve uzlaşma stillerini kullanması ile örgüt sağlığı arasında pozitif yönde yüksek derecede ilişki olduğu görülmüştür. Rahim' e $(1985,2001)$ göre çatışma taraflarının her ikisi için de kabul edilebilir bir çözüm yöntemi olan tümleştirme stili problem çözme olarak da adlandırılmaktadır. Uzlaşma stili de tarafların uç noktalara ayrışmadan ortak bir nokta üzerinde müzakere etmesi olarak tanımlanmaktadır. Bu durumda okul yöneticilerinin çatışma durumlarında çözüme ulaşmak için farklııkları inceleyerek her iki tarafın da bir şeylerden vazgeçerek ortak 
noktaya ulaşma çabasının okulların örgütsel sağlık düzeylerini yüksek düzeyde arttırdığı söylenebilir. Çünkü Başaran' a (1998) göre sağlıklı okullarda ortaya çıkan çatışmaları örgütsel hedefler doğrultusunda çözüme ulaştırmak gerekir. Okul yöneticilerinin çatışma durumlarında kullandıkları bir diğer stil olan ve karşısındakinin endişelerini gidermek için kendi düşüncelerinden vazgeçmesi olarak tanımlanan ödün verme stilini kullanması ile örgüt sağlığı arasında pozitif yönde orta düzeyde ilişki olduğu görülmüştür. Karip' e (1999) göre Türkiye'de geleneksel bürokratik yapıya sahip kurumlarda astlarla üstler arasında "güç mesafesi" daha uzak olduğu için astların çatışma durumlarında üstlerin talepleri karşısında kendi intiyaçlarından vazgeçme olasılığı yüksektir. Ayrıca Rahim ve Bonoma' ya (1979) göre karşı taraf ile ilişkilerin korunması önemseniyorsa ödün verme stilinin kullanılması uygun görülmektedir. Bu durumda çatışma durumlarında taraflardan birinin çatışmanın yıkıcı etkiler yaratmadan sonlanması adına taleplerinden ödün vermesi çatışma sürecinin örgüt iklimine zarar vermesini engelleyeceği söylenebilir. Araştırma kapsamında elde edilen regresyon analizi sonuçlarında da çatışma yönetim stillerinde tümleştirme, ödün verme ve uzlaşma stillerinin örgüt sağlığını anlamlı bir şekilde yordadığı görülmektedir. Çatışma yönetim stillerinden bir diğeri olan ve alanyazında çatışma taraflarından birinin kendi ihtiyaçları için karşısındakinin düşüncelerini yok sayması olarak tanımlanan hükmetme stili ile örgüt sağlığı arasında negatif yönde düşük derecede bir ilişki olduğu tespit edilmiştir. Ransom' un 1990 yılında okul sağlığı ile katılımcı yönetimin öğeleri arasındaki ilişkiyi belirlemek amacıyla yapmış olduğu çalışmada da okul yöneticilerinin emirleri doğrultusunda değil tüm çalışanların katılımıyla yönetilen okulların daha sağlıklı örgütler olduğu bulunmuştur (Akbaba, 1997). Bu durumda okul yöneticilerinin çatışma durumlarında okul yöneticilerinin kendi düşüncelerini karşı tarafa koşulsuz olarak kabul ettirmeye çalışması örgüt sağlığını olumsuz yönde etkilediği söylenebilir. Ayrıca geri çekilme (Rahim ve Bonoma, 1979), yada olumsuz hiçbir şey duymak istememe (Karip, 1999) olarak nitelendirilen okul yöneticilerinin kullandıkları çatışma yönetim stillerinden kaçınma stili ile örgüt sağlığı arasında anlamlı bir ilişki olmadığı görülmektedir.

Her örgütsel davranış araştırmasında olduğu gibi bu araştırmanında bazı sınırlılıkları bulunmaktadır. Bu sınırılıkların ilki okulların büyüklüğü, yöneticilerin kıdemi gibi farklııkların örgüt sağlığı ve çatışma yönetim stilleri üzerinde etkili olabileceği düşüncesidir. Dolayısıyla gelecekte yapılacak çalışmalarda araştırmacılar okulun büyüklüğü, okul yöneticisinin kıdemi gibi değişkenlerin incelenen ilişkide etkisi incelenmelidir. Araştırmadaki ikinci sınırlılık ise mevcut araştırma sonuçlarının tüm ülkeye genelleştirilebilmesi için ülkemizin her tarafını temsil edebilecek örneklemin farklı illerden alınarak araştırmanın tekrar edilmesi sağlanabilir. Böylece mevcut çalışmanın sonuçlarını tüm ülkeye genellemek mümkün olabilir. Araştırmadaki bir diğer sınırlılık ise yöneticilerin kullandıkları çatışma yönetim stilleri ile örgüt sağlığı arasındaki ilişkinin incelenmesinde aracı değişkenler olabilir. Bu nedenle gelecekte yapılacak çalışmalarda araştırmacılar her iki değişken arasındaki ilişkiye aracılık eden değişkenleri inceleyebilir.

Ulaşılan sonuçlar doğrultusunda ayrıca şu öneriler ileri sürülebilir: 
- Öğretmenlerin cinsiyetlerine ve çalıştıkları okul kademesine göre okul yöneticilerinin kullandıkları çatışma yönetim stillerinden hükmetme ve uzlaşma stillerindeki algıları değişmektedir. Bu durumun nedenleri nitel ve nicel çalışmalarla araştırılmalıdır.

- Çatışma yönetim stillerinden tümleştirme, ödün verme ve uzlaşma stillerinin kullanılması okulların örgüt sağlığını olumlu yönde etkilemektedir. Okul yöneticilerinin bu çatışma yönetim stillerini kullanmalarına yönelik çalışmalar yapılmalıdır.

- Okul yöneticilerinin kullandıkları çatışma yönetim stilleri ve etkilerini derinlemesine incelemek öğretmenlerin görüşlerini belirlemeye yönelik araştırmalar yapılmalıdır.

\section{Kaynaklar}

Akbaba, S. (1997). Ortaöğretim okullarının örgüt sağlığı (Bolu ili örneği) (Yayımlanmamış doktora tezi). Ankara Üniversitesi Sosyal Bilimler Enstitüsü, Ankara.

Aksu, A. (2003). Örgütsel çatışma yönetimi. Ege Eğitim Dergisi, 2(3), 99-107

Avcı, A. (2016). Effect of transformational and transactional leadership styles of school principals on organizational culture Okul müdürlerinin dönüşümcü ve işlemci liderlik stillerinin örgüt kültürüne etkisi. Journal of Human Sciences, 13(3), 4780-4807.

Ayduğ, D., \& Ağaoğlu, E. (2017). İlkokullarda örgüt sağlığı ile öğretmenlerin örgütsel güven düzeyleri arasındaki ilişkilerin incelenmesi. Anadolu Üniversitesi Eğitim Fakültesi Dergisi, 1(1), 1-17.

Ayık, A. \& Diş, O. (2015). Okul yöneticilerinin dönüşümcü liderlik rolleri ile örgüt iklimi arasındaki ilişkinin incelenmesi. Kuramsal Eğitimbilim Dergisi, 8(3), 337-359.

Bağdatlı, F. (2015). Okul yöneticilerinin çatışma yönetimi stilleri ile örgüt kültürü arasındaki ilişki (Yayımlanmamış yüksek lisans tezi). İstanbul Sabahattin Zaim Üniversitesi Sosyal Bilimler Enstitüsü, İstanbul.

Balcı, A. (2013). Sosyal bilimlerde araştırma yöntem, teknik ve ilkeler. Ankara: PEGEM Akademi.

Başaran, İ.E. (1994). Eğitim yönetimi, Ankara: Kadığlu Matbaası.

Başaran, İ. E. (1998). Yönetimde insan ilişkileri, yönetsel davranış. Ankara: Nobel.

Bayram, F. Y. (2012). İlköğretim okullarında müdürlerin yönetsel etkiliği ve okul iklimi ile öğrenci kontrol ideolojileri arasındaki ilişki (Yayımlanmamış yüksek lisans tezi). Eskişehir Osmangazi Üniversitesi Eğitim Bilimleri Enstitüsü, Eskişehir.

Buluç, B. (2008). Ortaöğretim okullarında örgütsel sağlık ile örgütsel vatandaşlık davranışları arasındaki ilişki. Türk Eğitim Bilimleri Dergisi, 6(4), 571-602.

Büyüköztürk, Ş. (2012). Sosyal bilimler için veri analizi el kitabı. Ankara: Akademi. 
Cemaloğlu, N. (2007). Okul yöneticilerinin liderlik stillerinin örgüt sağlığı üzerindeki etkisi. Türkiye Sosyal Araştırmalar Dergisi, 11 (2), 165-194

Çatakdere, K. (2014). Öğretmen algılarına göre ilköğretim kurumları (ilkokul-ortaokul) yöneticilerinin çatışma yönetimi stratejileri ile örgüt iklimi arasındaki ilişki (Yayımlanmamış yüksek lisans tezi). Okan Üniversitesi, Sosyal Bilimler Enstitüsü, İstanbul.

Çoban, N. (2007). Illköğretim okulu yönetici ve öğretmenlerinin örgüt sağlığına ilişkin algıları (Yayımlanmamış Yüksek Lisans Tez)i. Akdeniz Üniversitesi Sosyal Bilimler Enstitüsü, Antalya.

Diş, O. \& Ayık, A. (2016). Okul yöneticilerinin kullandıkları güç kaynakları ile örgüt iklimi arasındaki ilişki. Akademik Bakış Uluslararası Hakemli Sosyal Bilimler Dergisi, (58), 499-518.

Ebcim, Ö. P. (2012). Resmi ilköğretim okullarında çalışan öğretmenlerin motivasyonu ile örgüt sağlığı algıları arasındaki ilişki (Yayımlanmamış yüksek lisans tezi). Maltepe Üniversitesi, İstanbul.

Edwards, C. B. (2008). An investigation of the relationship between transformational leadership and organizational health (Yayımlanmamış doktora tezi). Capella University, Minneapolis.

Eren, E. (2016) Yönetim ve organizasyon, İstanbul: Beta Yayınları

Erol, E. (2009). IIlköğretim okulu yöneticilerinin çatışma yönetimi stratejileri ve bu çatışma yönetimi stratejilerinin öğretmenlerin stres düzeyine etkisi (Yayımlanmamış yüksek lisans tezi). Uşak Üniversitesi, Sosyal Bilimler Enstitüsü, UŞAK.

Follett, M. P. (1940). Constructive conflict. In h. c. metcalf \& I. urwick (eds.), dynamic administration: the collected papers of mary parker follett (pp. 30-49). New York: Harper \& Row. [originally published 1926]

Horata, C. S. (2013). İlköğretim okulu yöneticilerinin tercih ettikleri çatışma yönetimi stratejilerinin çeşitli değişkenler açısından incelenmesi(Denizli ili örneği) (Yayımlanmamış yüksek lisans tezi). Gazi Üniversitesi Eğitim Bilimleri Enstitüsü, Ankara.

Hoy, W. K., \& Feldman, J. A. (1987), Organizational health: the concept and its measure. Journal of Research and Development in Education, 20, Summer, 30-38.

Kapıcı, S. (2015). Eğitim örgütlerinde çatışma ve çatışma yönetimi üzerine bir araştırma: İzmir Balçova örneği (Yayımlanmamış yüksek lisans tezi). İstanbul Aydın Üniversitesi Sosyal Bilimler Enstitüsü, İstanbul.

Karagöz, M. (2016).SPSS 23 ve AMOS 23 uygulamalı istatistiksel analizler. Ankara: Nobel Akademik Yayıncılık.

Karasar, N. (2016). Bilimsel araştırma yöntemi. Ankara: Nobel Akademik Yayıncılık. 
Karcıoğlu, F., Gövez, E., \& Kahya, C. (2011). Yöneticilerin iletişim tarzı ve kullandıkları çatışma yönetim stili arasındaki ilişki. Atatürk Üniversitesi Sosyal Bilimler Enstitüsü Dergisi, 15(1).

Karip, E. (1999). Çatışma yönetimi. Ankara: Pegema Yayıncılık.

Kırçan, E. \& Bostancı, B. A. (2012). İlköğretim okulu yöneticilerinin çatışmayı yönetmede kullandıkları çatışma yönetimi stratejileri. Sakarya Üniversitesi Eğitim Fakültesi Dergisi, 24, 49-62

Koç, N.C. (2016). Illkokul öğretmenlerinin çatışma yönetimi stratejileri ile iş doyumları arasındaki ilişki(Tekirdağ/Kapaklı İlçesi Örneği) (Yayımlanmamış yüksek lisans tezi). İstanbul Sabahattin Zaim Üniversitesi Sosyal Bilimler Enstitüsü, İstanbul.

Koçak, S., \& Baskan, G. A. (2013). Okul müdürleri tarafından kullanılan çatışma yönetim yöntemlerinin etkililik düzeyleri. Hacettepe Üniversitesi Eğitim Fakültesi Dergisi, 44(44).

Korkmaz, M. (2011).İlköğretim okullarında örgütsel iklim ve örgüt sağlığının örgütsel bağlılık üzerindeki etkisi. Kuram ve Uygulamada Eğitim Yönetimi, 17(1), 117139.

Korkmaz, A. (2013). İlkokul ve ortaokul öğretmenlerinin çatışma yönetimi stratejileri ve iş doyumları arasındaki ilişkinin incelenmesi (Yayımlanmamış yüksek lisans tezi). Okan Üniversitesi Sosyal Bilimler Enstitüsü, İstanbul.

Miles, M. B. (1965). Planned change and organızatıonal health--figure and ground. Chapter 2, change processes in the publıc schools.

Odabaşıoğlu, F. (2013). İlkokul ve ortaokul müdürlerinin liderlik davranışları ve çatışma yönetimi stillerine ilişkin öğretmen algıları (Yayımlanmamış yüksek lisans tezi). Maltepe Üniversitesi Sosyal Bilimler Enstitüsü, İstanbul.

Ordu, A. (2011). İlköğretim okullarında örgütsel yapı ile örgüt sağlığı arasındaki ilişkiler (Yayımlanmamış doktora tezi). Pamukkale Üniversitesi, Denizli.

Önk, M. (2015). Illköğretim kurumu yöneticilerinin liderlik tarzları ile çatışmayı yönetme stratejileri arasındaki ilişki(Ankara ili örneği) (Yayımlanmamış yüksek lisans tezi). Gazi Üniversitesi, Eğitim Bilimleri Enstitüsü, Ankara.

Özdemir, A. (2006). Öğretmenlerin okullarını örgüt sağlığı açısından değerlendirmeleri (İzmir ili Bornova ilçesi örneği) (Yayımlanmamış yüksek lisans tezi). Pamukkale Üniversitesi Sosyal Bilimler Enstitüsü, Dneizli.

Polatçı, S., Ardıç, K., Adem, K. (2008). Akademik kurumlarda örgüt sağlığı ve örgüt sağlığını etkileyen değişkenlerin analizi.Celal Bayar Üniversitesi Iktisadi ve İari Bilimler Fakültesi Yönetim ve Ekonomi Dergisi, 15 (2), 145-161.

Rahim, M. A. (2001). Managing conflict in organizations. London: Westport, Connecticut, Quorum Books 
Rahim, M. A. (1983). A measure of styles of handling interpersonal conflict. The Academy of Management Journal. Vol.26, No.2, s.368-376.

Rahim, M. A. (1985). A Strategy for managing conflict in complex organizations. Human Relations, 38(1), 81-89.

Recepoğlu, E., \& Özdemir, S. (2013). Okul müdürlerinin öğretim liderliği davranışları ile okulun örgütsel sağlığı arasındaki ilişki. Kuram ve Uygulamada Eğitim Yönetimi Dergisi, 19(4), 629-664.

Şendur, E. F. (2006). Örgütsel çatışma ve çatışma yönetimi (Yayımlanmamış yüksek lisans tezi). Mersin Üniversitesi Sosyal Bilimler Enstitüsü, Mersin.

Taneri, A. (2011). Illköğretim kurumlarında etik liderlik ile örgüt sağlığı arasındaki ilişki. (Yayımlanmamış yüksek lisans tezi), Gazi Üniversitesi, Ankara.

Tanrıverdi, M. (2008). Ortaöğretim okulu yöneticilerinin öğretmenler tarafından algılanan çatışma yönetimi stilleri ile öğretmenlerin okul iklimi algıları arasındaki ilişki (Bursa ili örneği) (Yayımlanmamış yüksek lisans tezi). Yeditepe Üniversitesi, Sosyal Bilimler Enstitüsü, İstanbul.

Toytok, E., \& Açıkgöz, A. (2013). Öğretmen görüşlerine göre okul yöneticilerinin çatışma yönetim stilleri ile örgütsel adalet algıları arasındaki ilişki. E-AJELI (Anatolian Journal of Educational Leadership and Instruction), 1(2), 24-36.

Tuna, Z. (1996). Okul müdürlerinin yönetsel davranışlarının örgüt iklimine etkisi (Ankara ili örneği) (Yayımlanmamış yüksek lisans tezi). Ankara Üniversitesi Sosyal Bilimler Enstitüsü, Ankara.

Uğurlu, F. (2001). İlköğretim okulu müdürlerinin çatışma yönetme stilleri (Yayımlanmamış yüksek lisans tezi). Dokuz Eylül Üniversitesi, Eğitim Bilimleri Enstitüsü, İzmir.

Ural, A. (1997). Illköğretim okulu yöneticilerinin öğretmenlerle aralarındaki çatışmaları yöneltme yöntemleri (Yayımlanmamış doktora tezi). Abant İzzet Baysal Üniversitesi Sosyal Bilimler Enstitüsü, Bolu.

Uras, M. (2000). Lise öğretmenlerinin örgüt sağlığının moral, yenilikçilik, özerklik, uyum ve problem çözme yeterliği boyutlarına ilişkin algıları. PAÜ Eğitim Fakültesi Dergisi,(7).

Yıldızoğlu, H. (2013). Okul yöneticilerinin beş faktör kişilik özellikleriyle çatışma yönetimi stili tercihleri arasındaki ilişki (Yayımlanmamış yüksek lisans tezi). Hacettepe Üniversitesi Sosyal Bilimler Enstitüsü, Ankara.

Yiğit, İ. (2015). Ortaöğretim yöneticilerinin çatışma yönetimi stilleri (Trabzon örneği) (Yayımlanmamış yüksek lisans tezi). Okan Üniversitesi Sosyal Bilimler Enstitüsü, İstanbul.

Yüceler, A., Doğanalp, B., \& Kaya, Ş. D. (2013). The relation between organizational health and organizational commitment. Mediterranean Journal of Social Sciences, 4(10), 781. 